\title{
OBITUARIES
}

\section{GEOFFREY HEXT SUTHERLAND BUSHNELL, 1903-1978}

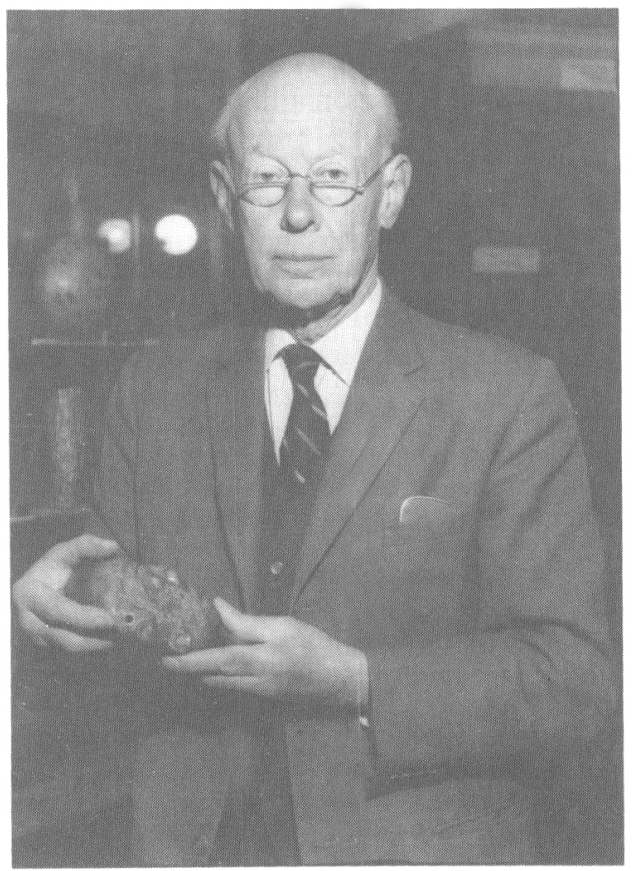

Geoffrey Bushnell was born in May 1903, the son of the Reverend G. D. S. Bushnell and Mildred Mary Earle. He was educated at Wellington College, a traditional British public school, and from there went as an undergraduate to Downing College, Cambridge. Although his antiquarian and archaeological interests dated back to schoolboy years, these subjects did not offer a career in the 1920 s, and Geoffrey took his degree in natural sciences.

It was geology rather than archaeology which led him to Ecuador. Graduating at a time when jobs were hard to find, he ignored the advice of his family and, against their wishes, accepted a position with Anglo-Ecuadorian Oilfields, with whom he remained from 1926 to 1938 . The work that established his archaeological reputation was a spare-time activity, carried out (as he wrote in the Preface to The Archaeology of the Santa Elena Peninsula) "with very moderate resources and in short periods of leisure in a busy life." During one such period, in 1936, he married Patricia Ruck, the sister of a friend and brass-rubbing colleague from Cambridge days (see 1947b). She went on to help him with the final stages of the research and was responsible for many of the published drawings. It was a partnership which gave Geoffrey great happiness, and which produced four sons.

In the quality of its fieldwork and in standards of presentation, the Santa Elena study was in advance of its time, and for many years it remained the cornerstone of coastal Ecuadorian archaeology and the stimulus for most future work there. Geoffrey had concentrated on the Guangala and Manteño periods, but he also excavated a Colonial cemetery and, at the other extreme, described some Valdivia sherds. He correctly placed these in a "pre-Guangala" stage, but in the days before radiocarbon dating, the very early date of this material was not yet apparent. In 1971 the Ecuadorian Government recognized the importance of this pioneering study by creating Geoffrey Comendador al Mérito of Ecuador.

The Ecuadorian research was his only published fieldwork, though in 1955 he carried out surveys and excavations in Tobago under circumstances which are now difficult to reconstruct. The finds remain unpublished (Cambridge University Museum of Archaeology and Anthropology collection no. 1957: 115-157), but from a manuscript account sent to Professor Irving Rouse it ap- 
pears that Geoffrey arrived in Tobago in March and left in late April: "about 4 weeks were spent in reconnaissance, including a voyage round the island in the coasting steamer Trinidad, to visit areas which were difficult of access by road. The rest of the time was spent in making trial excavations in the Mount Irwin and Plymouth areas." The Cambridge collection covers the series of local pottery styles from about the seventh century A.D. until the Conquest.

Apart from this West Indian venture, Geoffrey never excavated again, and from 1938 his career took a new direction. In that year he left the oil industry and returned to Cambridge to work on his Ecuadorian material. The key figure in this transitional period was Louis Clarke, at that time Curator of the Museum at Cambridge. Geoffrey had sent his first batch of Santa Elena sherds to Clarke. "The result," as he noted in his obituary for Clarke, "was an enthusiastic letter, painting the importance of the material in the most vivid terms and imploring me to get some more, which was of the greatest encouragement to a young man ploughing a lonely furrow far away" (1961a:192). Now Clarke persuaded him that the results should be worked up into a thesis for the Ph.D. degree, which was still something of a novelty in the Thirties. These studies were interrupted by the outbreak of war. During the war years Geoffrey was mainly engaged in the preparation of military maps, finishing as a major in the Royal Engineers. Throughout this period he kept up his connection with the museum, helping to pack its treasures for safe keeping at the start of hostilities, and unpacking them at the end of the war.

In 1946 he returned to Cambridge, becoming Assistant Curator of the Museum in 1948 and Curator a year later, a post which he held until his retirement in 1970.

Cambridge was to be his home for the rest of his life, and it provided the ideal setting for his varied and miscellaneous talents. The university takes delight in its traditions, and it tolerates-perhaps even encourages-personal idiosyncrasy as long as this is allied with professional competence. Geoffrey was a sociable person, and completely unselfconscious. The innocent visitor, meeting him for the first time, began by being slightly unnerved, and ended by being delighted, as well as better informed. Latin American students, accustomed to a more formal style, returned to London in a state of happy shock after a Bushnell consultation, with tales of a besandaled (and often sockless) individual, with a great cackling laugh and a shiny head surrounded by its rim of duck fluff, and with an endless stream of funny-and frequently scandalous-stories in English and Spanish. They sampled his fearsome snuff (usually only once), ate apples from the woven alforja which accompanied him everywhere (and served as the scale in so many of his photographs), and then went back for a very English tea at the house in Wordsworth Grove. For most of them, their final glimpse of the doyen of British Americanists was the distant view of a figure weaving dangerously on a bicycle through Cambridge traffic, en route to the next appointment.

As a teacher, Geoffrey was at his best in this kind of informal setting. He gave lectures on American archaeology and on material culture to a department which took neither of these things seriously, and it was not until 1966 that the university recognized his academic distinction by electing him Reader in New World Archaeology. National honors followed in 1970, when he was made a Fellow of the British Academy.

But the center of Geoffrey's academic life was the museum. He ran this, or at least the American section of it, like a private collection, and with a scorn for unnecessary bureaucracy. He wheedled type specimens out of his friends and students in order to build up one of the best small reference collections in the country, and he believed it was there to be used. As a self-taught Americanist, he encouraged others to take the same path and readily unlocked the museum's files for anyone with a serious inquiry. Like most good museum archaeologists, Geoffrey thought through his fingertips and believed that objects should be handled and tried out. One of his favorite reminiscences was of the visiting musicologist who managed to get a tune out of one of the museum's penis sheaths, under the impression that it was a flute. True to his principles, Geoffrey himself would just as happily blow conch trumpets to amuse small boys, demonstrate the atlatl for undergraduate classes (a dangerous experience, this), or pick over his Peruvian textiles with international specialists. 
He had little time for pure theory, and never wrote a theory paper himself. Having worked as a real scientist, he had no patience with the pretensions of pseudoscience and the jargon which so often accompanies it. He preferred to let the facts speak for themselves, and he supported the oldfashioned virtues of literacy, courtesy, and common sense-qualities which made him a popular chairman or panel member of conferences in the United States as well as in Britain. Several of his papers were first delivered at such meetings (1971a, 1971b, 1976).

His bibliography reflects his changing contribution to American archaeology: first the field research, then a series of notes (often for the Congress of Americanists) on items from the museum's collections, and finally, in his later years, a series of review articles and works of popularization. Of these, his Peru (1957) was the standard reference text for many years. Above all, for many of us Geoffrey was our only link with the world of transatlantic scholarship. In those days, when no university offered serious degree courses in American archaeology, it was the Cambridge Museum and the British Museum which between them kept the subject alive, and there were times when it was a very close thing. Generations of undergraduate expeditions asked his advice, and those of us who managed to stay in New World archaeology habitually raided his library and slide collection, and begged introductions to his wide network of personal contacts.

Although his friends were many and cosmopolitan, Geoffrey was, and took pride in being, a traditionalist. He enjoyed college life as a fellow of Corpus Christi from 1963, and in Who's Who he listed his recreations as gardening and visiting ancient buildings. He was a practicing Christian, with an interest in all aspects of liturgy, church architecture, and ecclesiastical antiquarianism, and in a practical way, he served his church as a member of the Cathedrals Advisory Committee and as a trustee of the Historic Churches Preservation Trust until the time of his death. Besides architecture, he had a detailed knowledge of heraldry, monumental brasses, and silver plate. Although not himself a great collector, one of his personal treasures was a fine Colonial Spanish silver jug, which (in an attempt to disguise its value) he would use to refill the car radiator in Santa Elena. It is fitting that one of his last publications (1975) was a study of the silver belonging to his own college.

Until illness slowed him down during his last three years, Geoffrey took enormous pleasure in everything he did, believing that wit and humor should enliven even serious discussions, and that scholarship is something to be enjoyed. His death, on 26 December 1978, following so closely on that of his friend Eric Thompson, marks the end of an era for American archaeology in Britain.

Acknowledgments. It is typical of Geoffrey Bushnell that he kept neither a curriculum vitae nor a complete set of his own publications. In preparing this obituary I have drawn on the memories of his friends, and have been greatly helped by discussions with Pat Bushnell, Mary Cra'ster, Peter Harris, Olaf Holm, and Irving Rouse.

\section{WARWICK BRAY}

\section{PRINCIPAL BIBLIOGRAPHY OF GEOFFREY BUSHNELL}

I have not attempted to include the many book reviews, short notices (of meetings, new journals, etc.), or contributions to the correspondence pages of Man. Even so, this list is certainly incomplete.

1946 An archaeological collection from Macas, on the eastern slopes of the Ecuadorian Andes. Man 46:2-6.

19478 (with Irwin Bullock). Art of ancient America. Exhibition Catalogue, Berkeley Galleries, London.

1947b (with G. A. E. Ruck). The monumental brasses of Northamptonshire. Reports and Papers of the Northamptonshire Architectural and Archaeological Society 53:1-19.

1949a Some old Western Eskimo spear-throwers. Man 49:121.

1949b Peru before Pizarro. Antiquity 23:136-139.

1949c (with C. I. Fell and T. C. Lethbridge). Archaeological notes. Proceedings of the Cambridge Antiquarian

Society 42:128-130.

1951 The archaeology of the Santa Elena Peninsula in south-west Ecuador Cambridge University Museum of Archaeology and Ethnology, Occasional Paper No. 1.

1952a The stone carvings of Manabí, Ecuador. Proceedings of the 20th International Congress of Americanists: 58-60.

1952b The origin of maize. Antiquity 26:92. 
1952c Comentario sobre "A note on the Archaeology of Southern Coastal Ecuador." Revista del Museo Nacional 21:208-209. Lima.

1952d (with C. I. Fell). Archaeological notes. Proceedings of the Cambridge Antiquarian Society 44:47-48. 1953 (with J. G. Hurst). Some further examples of Sgraffito ware from Cambridge. Proceedings of the Cambridge Antiquarian Society 46:21-26.

1955a Some Pueblo IV pottery types from Kechipaun, New Mexico, U.S.A. Anias de 31 Congreso Internacional de Americanistas: 657-665. São Paulo.

1955b (with Adrian Digby). Ancient American pottery. Faber and Faber, London.

1957 Peru. Thames and Hudson, London.

1959 a Some post-Columbian whistling jars from Peru. Actas del 33 Congreso Internacional de Americanistas 2:416-420. San José.

1959b A medieval leather box from Ellington, Hunts. Proceedings of the Cambridge Antiquarian Society 52:56-57.

1959c (with Charles McBurney). New World origins seen from the Old World. Antiquity 33:93-101.

1960 (with MDC). Pagan Saxon burials at Ely. Proceedings of the Cambridge Antiquarian Society 53:57.

1961a Louis Colville Gray Clarke, 1881-1960. Man 61:191-192.

1961b Peruvian textiles in the Burrell Collection. Scottish Art Review 8(1):22-25.

1961c A Cupisnique bird jar. In Essays in pre-Columbian art and archaeology, by S. K. Lothrop et al., pp. 266-268. Harvard University Press.

1961d Radiocarbon dates and New World chronology. Antiquity 35:286-291.

1961e An Old World view of New World prehistory. American Antiquity 27:63-70.

1962 The crimson-tipped flower: the birth and growth of New World civilization. In The dawn of civilization, edited by Stuart Piggott, pp. 359-386. Thames and Hudson, London.

1964 An Olmec jade formerly belonging to Alfred Maudslay. Actas y Memorias del 35 Congreso Internacional de Americanistas 1:541-542.

1965 Ancient arts of the Americas. Thames and Hudson, London.

1966 Some archaeological discoveries from the frontier region of Peru and Ecuador, near Jaen. Actas y Memorias del 31 Congreso de Americanistas 1:501-507. Seville.

1966-67 The Vicus pottery style of northern Peru: some hitherto undescribed examples. Folk 8-9:63-68.

1968 The first Americans: the pre-Columbian civilizations. Thames and Hudson, London.

1971a Commentary on "The civilizational consequences of varying degrees of agricultural and ceramic dependency within the basic ecosystems of Mesoamerica. Contributions of the University of California Archaeological Research Facility 11:349-251.

1971b Text of lecture delivered November 5, 1970 at University of Illinois, Urbana. Journal of the Steward Anthropological Society 3:54-68.

1974a Kunst in Ecuador. In Das alte Amerika: Band 18 Propyläen Kunstgeschichte, edited by Gordon R. Willey, pp. 275-285. Propyläen Verlag, Berlin.

1974b (with T. C. Patterson). Andean civilizations, history of. In Encyclopedia Britannica (15th ed.).

1975 (with R. I. Page). Matthew Parker's legacy: books and plate. Corpus Christi College, Cambridge.

1976 The beginning and growth of agriculture in Mexico. Philosophical Transactions of the Royal Society, London B. 275:117-120.

1977 William Wilkins, M.A., 1778-1839. Address delivered in the Chapel of Corpus Christi College, Cambridge at the Commemoration of Benefactors on 2 December 1977. Corpus Christi College, Cambridge.

n.d. Intreccio. In Enciclopedia Universale dell'Arte 7:610-619. Instituto per la Collaborazione Culturale, Venice-Rome.

Note: A fund in memory of Geoffrey Bushnell has been established to provide an annual traveling fellowship and/or visiting lectureship at Cambridge University. Donations, which are tax deductible, may be made through the American Friends of Cambridge University, Gordon Williams, President, 1611 35th St., N.W., Washington, D.C. 20007, to whom any other inquiries about the Bushnell Fund should also be directed. 